\title{
The Effect of Teacher Burnout on Organizational Commitment in Turkish Context
}

\author{
Öznur Ataş Akdemir \\ Correspondence: Öznur Ataş Akdemir, Faculty of Education, Fırat University, Elazı̆̆, Turkey.
}

Received: February 18, 2019

doi:10.11114/jets.v7i4.4067
Accepted: March 14, $2019 \quad$ Online Published: March 19, 2019

URL: https://doi.org/10.11114/jets.v7i4.4067

\begin{abstract}
The aim of this research is to determine the effect of teachers' burnout on their organizational commitment. The model of this research is correlational survey model. The participants of the study are 173 teachers working at elementary and secondary schools in Turkey. Maslach Burnout Inventory and Organizational Commitment Scale are used as data collection instruments. For data analysis, Pearson correlation analysis, and basic and multiple regression analysis are applied with SPSS. The findings of the study showed that emotional exhaustion dimension of burnout and compliance dimension of organizational commitment in terms of teachers' perceptions were found at high level in comparison with other dimensions of burnout and organizational commitment. Also, it is determined that there is a negative, moderate and significant relationship between teachers' burnout and their organizational commitment. Besides, teachers' organizational commitment significantly predict their burnout. The findings of this research are discussed with related studies and some implications are presented.
\end{abstract}

Keywords: teachers, burnout, organizational commitment

\section{Introduction}

The effectiveness and productivity of an organization can be achieved with its management and employees. The employees are expected to have a high level of commitment towards the organization in order to devote their time, ambition and effort to the organization. There is no doubt that the level of commitment of an employee may change depending on some variables. Burnout is one of the variables which have effect on commitment. This paper aims at investigating the two concepts, teachers' organizational commitment and their burnout in the light of relevant literature. The paper extends its inquiry to investigate the effect of teachers' burnout on their organizational commitment in a correlational survey study model.

\subsection{Burnout}

As a work-related problem, burnout is defined as 'physical, mental or emotional exhaustion caused by long-term involvement' in demanding workplace environment (Harrison, 1999:25). Maslach, Schaufeli and Leiter (2001) identified the dimensions of burnout as emotional exhaustion, depersonalization and loss of the sense of personal accomplishment. Emotional exhaustion is defined as the consumption of one's emotional resources; depersonalization refers to detached attitude towards people at workplace; and the loss of personal accomplishment is defined as a state of ineffectiveness and inadequacy towards job performance and the situations faced at workplaces (Togia, 2005; Toker, 2011). The most important dimension of burnout is emotional exhaustion (Tuğrul \& Çelik, 2002) as it leads to losing the energy to continue the job. The term itself is associated with stress, fatigue and frustration experienced at working environments especially by those who are constantly in contact with other people (Arvidsson et al., 2016; Jacobson, 2016; Özdemir \& Demir, 2017). Teachers are among those professionals who experience burnout at a highest levels. Several studies have been devoted to defining, identifying and investigating teachers' burnout (Friesen, Prokop \& Sarros, 1988; Hock, 1988; Koustelios, 2001; Sarros \& Sarros, 1987; Şahin, 2007).

Teachers are reported to experience several physiological and psychological problems stemming from burnout (Tuğrul $\&$ Çelik, 2002) as teaching profession is stated to be one of the most stressful jobs (Antoniou et al., 2000). The relevant literature provides an exhaustive list of reasons of burnout for teachers. These are financial issues and time management problems (Guglielmi \& Tatrow, 1998); classroom size, classroom population, school type (Sucuoğlu \& Kuloğlu, 1996); discipline problems caused by students, external intervention to teaching practice, policy changes (Farber, 1984); and lack of support for stress sources (Çokluk, 2000). Among all, stress is the leading factor of burnout. It is crucial to 
define the causes and sources of stress as well as providing teachers the ways of coping with them in order to prevent burnout (Muller, Gorrow, \& Fiala, 2011; Tuğrul \& Çelik, 2002). If not treated or prevented, burnout may cause neglecting or quitting job, losing the passion towards teaching, having problems with colleagues, friends, students or family (Erçen, 2009).

\subsection{Organizational Commitment}

Any organization exists and survives with its members. In order to ensure the vitality and success of organizations, it is essential to keep members committed to the organization they work for. Organizational commitment implies the strength of attachment employee has towards the organization s/he work for (Güney, 2011). In other words, organizational commitment is formed by the attitudes of employees towards their organization. There are several other concepts which are associated with the definition of organizational commitment such as loyalty (Luthans, 1995), internalized normative forces (Wiener, 1982), identification with organization's values (Gaertner \& Nollen, 1989), willingness to endeavour for organization (Martin \& Bennet, 1996). Based on these conceptions, organizational commitment is formed by a) accepting and believing in the organizational values and aims, b) making extra effort to reach the organizational goals, and c) having a strong wish or willingness to sustain the membership of the organization (Allen \& Meyer, 1990; Vandenberg \& Scarpello, 1994). Though there are several other categorizations, one of the preferable categorization provides the dimensions of organizational commitment as follow: compliance, identification and internalization. These dimensions are consecutive. Compliance is defined an instrumental commitment based on awards (Güney, 2011). Compliance is the first and primitive step of commitment as its main drives are earning money, respect, power or promotion. Identification occurs if the values and beliefs of the organization are compatible with employees' attitudes and behaviours. Identification is a kind of commitment based on the coherence of employee's and organization's values (Güney, 2011). Employees expect that their values are compatible with the values of the organization. Internalization exists when this compatibility is realized. According to Güney (2011), internalization is the most commonly desired type of commitment for organizations. Organizational commitment is accepted as a vital element for the success and quality of educational organizations. Balay (2014) implies the relationship between teachers' organizational commitment and students' academic success. According to Kushman (1992) there is a mutual relationship between organizational commitment and success; that is teachers' organizational commitment not only affects students' success but also gets affected by students' success. Along with success, organizational commitment has close relationship with also organization's management. As Kaya, Balay and Tinaz (2014) stated, school managers' and teachers' managerial effectiveness predicts their organizational commitment in a positive way. The relevant literature provides lots of studies investigating organizational commitment from various perspectives and its relationships with different variables (Berkovich, 2018; Bikmaradi, Fardmal, \& Torabi, 2018; Liu \& Bellibas, 2018; Sari \& Seniati, 2018).

\subsection{Burnout and Organizational Commitment}

As a key concept in organizational structures, commitment has long been interrelated with burnout at various work contexts. Health organizations and schools are among the leading contexts in which professionals' commitment and burnout levels are studied. This is because of the nature of those professionals who are reported to be exposed to burnout more than other professionals. Some examples of research conducted in various types of organizations are as follow: nurses (Demirel, Tohum \& Kartal, 2017), call center employees (Ağraş \& Genç, 2018), professionals from health sector (Arık \& Turunç, 2016), and public managers (Meydan, Basım \& Çetin, 2011). The relationship between organizational commitment and teachers' burnout levels or status has been investigated at various contexts. Güneş, Bayraktaroğlu and Özen Kutanis (2009) implied the mediating roles of the two concepts on stress and organizational results. They conducted an experimental study in which data was collected through an organizational commitment scale and a burnout inventory. In another research, Çetin, Basım and Aydoğan (2011) conducted a correlational research on teachers and they found that organizational commitment has an important effect in explaining the dimensions of burnout. In an exploratory research study Nagar (2012) tested the relationship between burnout and organizational commitment in an indirect way. Nagar's study explored the relationship between burnout and job satisfaction in the first step, then the study expanded its inquiry to find out whether the three concepts are linked. Nagar found that burnout, with its all dimensions, causes decreased job satisfaction which in turn influences organizational commitment. Werang, Asmaningrum and Irianto (2013) conducted a quantitative research to determine the relationship between burnout, organizational commitment and job performance in an elementary school context. Their research findings indicated a close relationship between burnout and commitment as well as burnout with job satisfaction. Sajid (2014) compared the levels of organizational commitment and burnout levels of teachers at public and private schools. Most of the studies in the relevant literature focus on dimensions of burnout and commitment. For example depersonalization and normative commitment (Shirazi, Beiki, Zamanian \& Esapour, 2011), intellectual/emotional burnout and emotional commitment (Bulut, 2017), and emotional exhaustion and affective commitment (Li, 2014). 


\subsection{Aim of the study}

This research aims to investigate the effect of teachers' burnout on their organizational commitment. In this reason, following questions are tried to be answered in this study:

a) What are the levels of teachers' burnout and organizational commitment?

b) Is there any relationship between teachers' burnout and organizational commitment?

c) Do teachers' organizational commitment significantly predict their burnout?

\section{Method}

\subsection{Research Model}

In the present study, it is aimed to determine the effects of teachers' burnout level on their organizational commitment by examining the relationship between teachers' organizational commitment and their burnout levels. For this purpose, correlational survey model is applied.

\subsection{Participants}

One hundred seventy-three teachers who are working at public primary schools and public secondary schools in one of the provinces of Turkey are recruited for this study. Of the cohort of 173 teachers participating in the present study, 94 $(54,3 \%)$ are female and $79(45,7 \%)$ are male. In terms of teachers' professional degree, $70(40,5 \%)$ of whom have 1-5 years seniority, $52(30,1 \%)$ of whom have 6-10 years seniority, $26(15 \%)$ of whom have 11-15 years seniority, 18 $(10,4 \%)$ of whom have $16-20$ years seniority, $7(4 \%)$ of whom have 21 years and more seniority. Additionally, 78 (45, $1 \%)$ of the participants are elementary school teacher and $95(54,9 \%)$ of them are subject matter teacher.

\subsection{Data Collection Tools}

In this study, Maslach Burnout Inventory is used for collecting data to determine the teachers' burnout level while Organizational Commitment Scale is used for collecting data to determine the teachers' organizational commitment levels.

\subsubsection{Maslach Burnout Inventory}

In order to determine the level of teachers' burnout Maslach Burnout Inventory which is developed by Maslach and Jackson (1981) and adapted into Turkish by Ergin (1992) is used. This scale is composed of 20 items with five Likert-type grade. It includes three sub dimensions which are called as emotional exhaustion, depersonalization and loss of personal accomplishment. In this research, it is found that Cronbach alpha reliability coefficient that belongs to scale is 88. On the other hand, Cronbach alpha reliability coefficient that belongs to dimensions is found that reliability coefficient for emotional exhaustion is 83 , reliability coefficient for depersonalization is 72 and reliability coefficient for reduced personal accomplishment is 71 .

\subsubsection{Organizational Commitment Scale}

To determine the level of teachers' organizational commitment level Organizational Commitment Scale that is developed by Balay (200) is used. This scale is composed of 27 items with five Likert-type grade. This scale has three sub dimensions namely compliance, identification and internalization. Cronbach alpha coefficient is used to determine the level of reliability of the scale. In this process, both the total alpha coefficient of the scale and the alpha value of sub-dimensions are calculated as well. It can be stated that Cronbach alpha reliability coefficient which belongs to scale is 89 . On the other hand, Cronbach alpha reliability coefficient that belongs to dimensions is found that reliability coefficient for compliance is 70 , reliability coefficient for identification is 87 and reliability coefficient for internalization is 91 .

\subsection{Data Analysis}

Standard deviation, arithmetic mean, frequency, and percentage, correlation analysis, simple and multiple linear regression analysis are used for data analysis. Before correlation analysis and regression analysis between the variations are carried out, analysis of missing data and outliers are handled, normality, linearity and the problem of multicollinearity are examined. To test whether the set of data is normally distributed, coefficient of kurtosis and coefficient of skewness are employed. In the present study, the coefficient of skewness of the burnout is found as 0.15 . In terms of sub dimensions of burnout, the coefficient of skewness is found as 0.28 for emotional exhaustion, 0.80 for depersonalization and -0.03 for less personal accomplishment. Additionally, the coefficient of kurtosis of the burnout is found as -0.52 . On the other hand, the coefficient of kurtosis regarding sub dimensions of burnout is found as -0.62 for emotional exhaustion, 0.42 for depersonalization and -0.44 for loss of personal accomplishment.

When coefficient of skewness regarding organizational commitment is checked, it is found as -0.03 . On the other hand, the coefficient of skewness related to sub dimensions of organizational commitment is found as -1.36 for 
compliance, 0.13 for identification and -0.17 for internalization. Addition to these statistical data, the coefficient of kurtosis regarding organizational commitment is found as -0.28. In terms of sub dimensions of organizational commitment, the coefficient of kurtosis is found as 1.91 for compliance, -0.52 for identification and -0.35 for internalization. According to these findings, the data can be accepted as normally distributed. To determine whether there is multicollinearity problem between variables, the binary correlation between independent variables and dependent variables are investigated and it is found that the variables aren't too highly correlated to create problems related to multicollinearity.

\section{Results}

Descriptive statistics related to variables of the present study and the relationships between these variables are shown in Table 1.

Table 1. Mean and Standard Deviation of Variables and Relations among Variables

\begin{tabular}{|c|c|c|c|c|c|c|c|c|c|c|}
\hline Variables & $\mathrm{M}$ & $\mathrm{Sd}$ & 1 & $1 \mathrm{a}$ & $1 \mathrm{~b}$ & $1 \mathrm{c}$ & 2 & $2 a$ & $2 b$ & $2 \mathrm{c}$ \\
\hline 1.Burnout & 2.27 & .52 & - & & & & & & & \\
\hline 1a. Emotional Exh. & 2.54 & .68 & $.90 * *$ & - & & & & & & \\
\hline 1b. Depersonalization & 1.88 & .68 & $.82 * *$ & $.62 * *$ & - & & & & & \\
\hline 1c.Loss of Pers. Accomp. & 2.21 & .50 & $.77 * *$ & $.48 * *$ & $.52 * *$ & - & & & & \\
\hline 2.Org. Com. & 3.70 & .54 & $-.40 * *$ & $-.32 * *$ & $-.31 * *$ & $-.38 * *$ & - & & & \\
\hline 2a.Compliance & 4.23 & .60 & $-.44 * *$ & $-.45 * *$ & $-.40 * *$ & $-.23 * *$ & $.61 * *$ & - & & \\
\hline 2b.Identification & 3.20 & .87 & $-.15^{*}$ & -.13 & -.05 & $-.19 *$ & $.82 * *$ & $.31 * *$ & - & \\
\hline 2c.Internalization & 3.64 & .66 & $-.34 * *$ & $-.20 * *$ & $-.29 * *$ & $-.42 * *$ & $.84 * *$ & $.26^{* *}$ & $.54 * *$ & - \\
\hline
\end{tabular}

$* * \mathrm{p}<.01 ; * \mathrm{p}<.05$

As Table 1, shows that according to teachers' perceptions, the distributions related to burnout and organizational commitment are investigated and the following results are found. In terms of sub dimension of burnout, the highest mean belongs to emotional exhaustion $(\mathrm{M}=2.54)$ while the lowest mean belongs to depersonalization $(\mathrm{M}=1.88)$. When the distributions regarding organizational commitment is examined, it can be seen that the highest mean belongs to compliance $(\mathrm{M}=4.23)$ which is one of the sub dimensions of organizational commitment and the lowest mean belongs to internalization $(\mathrm{M}=3.20)$ which is one also one of three sub dimensions of organizational commitment.

When the correlation coefficients between variables are investigated, it is clear that there is a negative, medium level and significant relationship between burnout and organizational commitment $(r=-.40, p<0.01)$. Furthermore, there is a negative and significant relationship between sub dimensions of burnout and the sub dimensions of organizational commitment. The strongest relationships between the sub dimensions of burnout and sub dimensions of organizational commitment are seen between emotional exhaustion and compliance $(r=-.45, \mathrm{p}<.01)$, loss of personal accomplishment and internalization $(\mathrm{r}=-.42, \mathrm{p}<.01)$, depersonalization and compliance $(\mathrm{r}=-.40, \mathrm{p}<.01)$. Additionally, there is not significant relationship between emotional exhaustion, depersonalization and identification.

The findings related to sub dimensions of organizational commitments in the prediction of emotional exhaustion, which is one of the sub dimensions of burnout, are shown in Table 2.

Table 2. The Results of Regression Analysis Regarding Sub dimensions of Organizational Commitment in the prediction of Emotional Exhaustion

\begin{tabular}{llllll}
\hline Variables & $\mathrm{B}$ & $\mathrm{S} . \mathrm{E}$. & $\beta$ & $\mathrm{t}$ & $\mathrm{p}$ \\
\hline Constant & 4.96 & .38 & & 13.07 & .00 \\
Compliance & -.50 & .08 & -.44 & -6.04 & .00 \\
Identification & .06 & .07 & .07 & 0.87 & .39 \\
Internalization & -.13 & .09 & -.13 & -1.57 & .12 \\
\hline
\end{tabular}

$\mathrm{R}=0.46 \quad \mathrm{R}^{2}=0.21 \quad \mathrm{~F}=15.13 \quad \mathrm{p}=0.00$

According to Table 2, there is a significant relation between compliance, identification, internalization and emotional exhaustion $(\mathrm{R}=0.46, \mathrm{R} 2=0.21, \mathrm{p}<.01)$. According to this result, these predictor variables (compliance, identification, internalization) explain the variance of emotional exhaustion at level of $21 \%$. According to the standardized regression index $(\beta)$ and t-scores, it can be said that compliance is a significant predictor of emotional exhaustion.

The findings related to the sub dimensions of organizational commitments in the prediction of depersonalization that is one of the sub dimensions of burnout are shown in Table 3. 
Table 3. The Results of Regression Analysis Regarding dimensions of Organizational Commitment in the prediction of Depersonalization

\begin{tabular}{llllll}
\hline Variables & $\mathrm{B}$ & $\mathrm{S} . \mathrm{E}$. & $\beta$ & $\mathrm{t}$ & $\mathrm{p}$ \\
\hline Constant & 4.38 & .37 & & 11.82 & .00 \\
Compliance & -.45 & .08 & -.39 & -5.53 & .00 \\
Identification & .20 & .06 & .25 & 3.12 & .00 \\
Internalization & -.34 & .08 & -.33 & -4.12 & .00 \\
\hline
\end{tabular}

$\mathrm{R}=0.49 \quad \mathrm{R}^{2}=0.24 \quad \mathrm{~F}=17.96 \quad \mathrm{p}=0.00$

As shown in Table 3, there is a significant relationship between compliance, identification, internalization and depersonalization $(\mathrm{R}=0.49, \mathrm{R} 2=0.24, \mathrm{p}<.01)$. This result reveals that $24 \%$ of total variance of depersonalization is up to the variables that are mentioned namely compliance, identification, and internalization. When the standardized regression index $(\beta)$ and t-scores are examined, it can be said that compliance, identification, internalization are significant predictors of depersonalization.

The findings related to the dimensions of organizational commitment in the prediction of loss of personal accomplishment, which is one of the dimensions of burnout, are given in Table 4.

Table 4. The Results of Regression Analysis Regarding Sub dimensions of Organizational Commitment in the prediction of Loss of Personal Accomplishment

\begin{tabular}{llllll}
\hline Variables & $\mathrm{B}$ & $\mathrm{S} . \mathrm{E}$. & $\beta$ & $\mathrm{t}$ & $\mathrm{p}$ \\
\hline Constant & 3.77 & .28 & & 13.33 & .00 \\
Compliance & -.13 & .06 & -.15 & -2.02 & .04 \\
Identification & .05 & .05 & .08 & 0.97 & .33 \\
Internalization & -.33 & .06 & -.42 & -5.11 & .00 \\
\hline
\end{tabular}

$\mathrm{R}=0.44 \quad \mathrm{R}^{2}=0.20 \quad \mathrm{~F}=13.61 \quad \mathrm{p}=0.00$

According to Table 4, there is a significant relationship between compliance, identification, internalization and loss of personal accomplishment $(\mathrm{R}=0.44, \mathrm{R} 2=0.20, \mathrm{p}<.05)$. This result shows that these predictor variables (compliance, identification, internalization) explain the variance of loss of personal accomplishment at level of $20 \%$. When the standardized regression index $(\beta)$ and t-scores are examined, it is seen that compliance and internalization are significant predictors of loss of personal accomplishment.

The findings related to organizational commitments in the prediction of burnout are given in Table 5 .

Table 5. The Results of Simple Linear Regression Analysis Regarding Organizational Commitment in the prediction of Burnout

\begin{tabular}{|c|c|c|c|c|c|}
\hline Variables & $\mathrm{B}$ & S.E. & $\beta$ & $\mathrm{t}$ & $p$ \\
\hline Constant & 3.69 & .25 & & 14.57 & 0.00 \\
\hline Org. Com. & -.38 & .07 & -.40 & -5.64 & 0.00 \\
\hline $\mathrm{R}=0.40 \mathrm{R}^{2}=0.16 \mathrm{~F}=31.81$ & $\mathrm{P}=0.000$ & & & & \\
\hline
\end{tabular}

\section{Conclusion, Discussion and Recommendations}

The purpose of this paper is to determine the effects of teachers' burnout level on their organizational commitment by examining the relationship between teachers' organizational commitment and their burnout levels. The results of the present study indicate that there is a negative and significant relationship between teachers' burnout level and their organizational commitment. Additionally, teachers' perceptions regarding organizational commitment play a significant role as a predictor of teachers' perceptions regarding burnout.

When the results of the research are examined, it is found that teachers' burnout level is low and they show the highest level of burnout in emotional exhaustion sub dimensions. It can be said that teachers show the highest level of burnout when it is compared with the other professions because of the fact that teaching profession makes teachers emotionally spent and this profession requires to sacrifice and effective communication (Baltaş \& Baltaş, 1993). In reviewing the literature, it is seen that the results of the studies namely Girgin and Baysal (2005), Karacan (2012), Kırılmaz, Çelen and Sarp (2003) and Ulutaşdemir (2012) support the results of the present study. In reference to their work which aims to investigate the burnout levels of special education teachers, Girgin and Baysal (2005) determine that teachers show higher level of burnout. The study which is conducted by Karacan (2012) reveals that the teachers who work at private schools display the highest level of burnout in emotional exhaustion subdimension. According to findings of the study in which participants are recruited from a group of teachers who work at primary education, Kırılmaz, Çelen and Sarp 
(2003) explain that teachers experience emotional exhaustion. When Ulutaşdemir (2012) investigates the factors which affect the teachers' burnout levels, she finds that values regarding teachers' emotional exhaustion are higher than the values related to the other dimensions. In contradistinction to this finding, Gündüz (2012) states that school counselors show the highest level of burnout in depersonalization sub dimensions.

In the present study examining the teachers' organizational commitment levels, it is found that teachers mostly feel committed in compliance sub dimensions. On the other hand, teachers' organizational commitment level is low in identification which is another sub dimension of organizational commitment. The results of the studies which are conducted on organizational commitment reveal that teachers' organizational commitment levels are higher in internalization when it is compared with the other sub dimensions. (Erdaş, 2009; Kul \& Güçlü, 2010; Sezer, 2005). As a result of the study which gives an account of organizational commitment levels of primary education teachers, it is found that teachers have high level of organizational commitment in internalization (Erdaş, 2009). Similarly, in their research which is conducted to determine the organizational commitment level of physical education teachers, Kul and Güçlï (2010) detect that teachers display higher level of organizational commitment in internalization while they display lower level of organizational commitment in compliance. Sezer (2005) also reports that teachers are mostly committed to school in internalization sub dimensions.

According to the results of the study, it is found that there is a negative and significant relationship between teachers' burnout levels and their organizational commitment levels. In other words, the more teachers' burnout levels decrease, the more their organizational commitment levels increase. Furthermore, organizational commitment plays a significant role as a predictor of teachers' burnout levels. The fact that teachers have higher organizational commitment levels leads to decrease in burnout. Previous studies in the literature regarding the relationship between organizational commitment and burnout level, support results of the present study. (Arık \& Turunç, 2016; Bulut, 2017; Çetin, Basım \& Aydoğan, 2011; Çutuk, 2011; Demirel, Tohum \& Kartal, 2017; Güneş, Bayraktaroğlu \& Özen Kutanis, 2009; Haghani, Hazraty \& Moosivand, 2016; Sajid, 2014; Werang, Asmaningrum \& Irianto, 2013; Yasmin \& Marzuki, 2015). Arık and Turunç (2016) find that burnout levels of employees from the health sector are negatively related to organizational commitment. As a result of the study examining the relationships between academicians' organizational commitment level and their burnout level, Bulut (2017) detects that there are significant relationships between academicians' organizational commitment level and their burnout level. As a consequence of the study conducted to explore the relationship between teachers' burnout level and their organizational commitment level, Çetin, Basım and Aydoğan (2011) state that there are significant correlations between organizational commitment's sub dimensions and burnout sub dimensions. Çutuk (2011) finds that burnout levels of sport club employees have an impact on their organizational commitment. Demirel, Tohum and Kartal (2017) hold a study on nurses to determine the effect of burnout on organizational commitment and they reveal that burnout has an effect on organizational commitment. The findings of the study which is conducted in a state university by Güneş, Bayraktaroğlu and Özen Kutanis (2009) show that there are significant relationships between employees' organizational commitment and their burnout levels. Additionally, Haghani, Hazraty and Moosivand (2016) find that there is a significant relationship between organizational commitment and burnout as a result of the data collected from employees working at social security association. Sajid (2014) analyzes the data collected from teachers and he concludes that there is a significant relationship between organizational commitment and burnout and he reveals that job satisfaction plays a mediating role. Werang, Asmaningrum and Irianto (2013) deduce that there are significant relationships between occupational burnout and organizational commitment. The results of the study which is designed by Yasmin and Marzuki (2015) reveals that normative commitment has a significant impact on nurse's burnout levels.

The results of the study reveal that organizational commitment has an effect on teachers' burnout levels. In this aspect, the following suggestions are listed by the help of the results of the present study: Because of the fact that teachers have high level of emotional exhaustion, there must be some adjustment regarding this topic to decrease the level of emotional exhaustion. Teachers mostly feel committed in compliance sub dimensions which means that teachers fail to fully internalize their profession. In this aspect, panels and workshops can be held to make teachers internalized their own profession.

\section{References}

Ağraş, S., \& Genç, E. (2018). Örgütsel bağlılık ve tükenmişlik sendromu ilişkileri: Çağrı merkezi çalışanlarına yönelik nitel bir araştırma [The relations of organizational commitment and burnout: A qualitative research on a call center employee]. Uluslararası Batı Karadeniz Sosyal ve Beşeri Bilimler Dergisi, 2(1), 35-55.

Allen, N. J., \& Meyer, J. P. (1990). The measurement and antecedents of affective, continuance and normative commitment to the organization. Journal of Occupational Psychology, 63(1), 1-18. https://doi.org/10.1111/j.2044-8325.1990.tb00506.x

Antoniou, A. S., Polychroni, F., \& Walters, B. (2000, July). Sources of stress and professional burnout of teachers of special educational needs in Greece. In International Special Education Congress. 
Arık, A., \& Turunç, Ö. (2016). Tükenmişlik ve Örgütsel Bağlllık İlişkisinde Demografik Değişkenlerin Rolü: Isparta Sağlık Çalışanlarında Bir Uygulama [The role of demographic factors in the relationship between burnout and organizational commitment: A research in education sector]. Toros Üniversitesi IISBF Sosyal Bilimler Dergisi, 3(6), 109-130.

Arvidsson, I., Håkansson, C., Karlson, B., Björk, J., \& Persson, R. (2016). Burnout among Swedish school teachers-a cross-sectional analysis. BMC public health, 16(1), 823. https://doi.org/10.1186/s12889-016-3498-7

Balay, R. (2000). Özel ve resmi liselerde yönetici ve öğretmenlerin örgütsel bağlılı̆̆ı: Ankara ili örneği [The organizational commitment of administrators and teachers in private and public secondart schools (Sample of Ankara province)]. Unpublished PhD Dissertation. Ankara Üniversitesi, Sosyal Bilimler Enstitüsü, Ankara.

Balay, R. (2014). Yönetici ve ögretmenlerde örgütsel bă̆lllık [Organizational commitment of principals and teachers]. (2.Edition) Ankara:Pegem Akademi.

Baltaş, A., \& Baltaş, Z. (1993). Stres ve başa çıkma yolları [Stress and coping with it]. İstanbul: Remzi Kitabevi.

Berkovich, I. (2018). Effects of Principal-Teacher Gender Similarity on Teacher's Trust and Organizational Commitment. Sex Roles, 78(7-8), 561-572. https://doi.org/10.1007/s11199-017-0814-3

Bikmaradi, A., Fardmal, J., \& Torabi, Y. (2018). Correlation of Learning Organization and Intensive Care Nurses' Organizational Commitment of Educational and Therapeutic Centers of Hamadan University of Medical Sciences in Iran. Revista Publicando, 5(15), 395-409.

Bulut, M. B. (2017). Akademisyenlerin örgütsel bağll1ıkları, kişilik özellikleri ve tükenmişlik düzeyleri arasındaki ilişkiler [The relationships between organizational commitment, personality traits and burnout levels of academicians]. Uluslararası Sosyal Araştırmalar Dergisi, 10(50), 362-370.

Çetin, F., Basım, H. N., \& Aydoğan, O. (2011). Örgütsel bağlılığın tükenmişlik ile ilişkisi: Öğretmenler üzerine bir araştırma [The relationship between organizational commitment and burnout: A study on teachers]. Selçuk Üniversitesi Sosyal Bilimler Enstitüsü Dergisi, 25, 61-70.

Çokluk, Ö. (2000). Örgütlerde Tükenmişlik: Yönetimde Çağdaş Yaklaşımlar [Burnout at organizations: Contemporary approaches to administration]. (Ed. Cevat Elma and Kamile Demir). Ankara: Ani Yayıncılık.

Çutuk, S. (2011). Spor işletmelerinde mesleki tükenmişlik ve örgütsel bağll1ık ilişkisi [The relationship between occupational and organizational commitment in sports establishments]. Unpublished Master's Thesis. Balıkesir Üniversitesi Sosyal Bilimler Enstitüsü, Balıkesir.

Demirel, Y., Tohum, E. U., \& Kartal, Ö. (2017). Tükenmişliğin örgütsel bağl1lık üzerine etkisi: Bir üniversite hastanesinde çalışan hemşireler üzerine araştırma [The effect of burnout on organizational commitment: A study on nurses in a university hospital]. Kastamonu Üniversitesi İktisadi ve İdari Bilimler Fakültesi Dergisi, 18(1), 444-460.

Erçen, A. E. Y. (2009). Öğretmenlerin mesleki tükenmişlik düzeyleri: Mersin ilinde karşılaştırmalı bir inceleme [Professional burnout levels of teachers: A comparative investigation in Mersin province]. Çukurova Üniversitesi Eğitim Fakültesi Dergisi, 3(36), 1-8.

Erdaş, Y. (2009). Denizli il merkezinde çalışan ilköğretim öğretmenlerinin örgütsel bağlllık düzeyleri [the organizational commitment level of the teachers who works at the primary schools within the city center of Denizli]. Unpublished Master's Thesis. Pamukkale Üniversitesi Sosyal Bilimler Enstitüsü, Denizli.

Ergin, C. (1992). Doktor ve hemşirelerde tükenmişlik ve Maslach tükenmişlik ölçeğinin uyarlanması [Burnout in doctors and nurses and an adaptation of Maslach burnout scale]. VII. Ulusal psikoloji kongresi bilimsel çalışmaları, $22,25$.

Farber, B. A. (1984). Stress and burnout in suburban teachers. Journal of Educational Research, 77, 325-331. https://doi.org/10.1080/00220671.1984.10885550

Friesen, D., Prokop, C. M., \& Sarros, J. C. (1988). Why teacher burnout. Educational Research Quarterly, 12 (3), 9-19.

Gaertner, K. N., \& Nollen, S. D. (1989). Career experiences, perceptions of employment practices, and psychological commitment to the organization. Human relations, 42(11), 975-991. https://doi.org/10.1177/001872678904201102

Girgin, G. \& Baysal, A. (2005). Zihinsel engelli öğrencilere eğitim veren öğretmenlerin mesleki tükenmişlik düzeyi ve bazı değişkenler (İzmir örneği) [Professional burnout levels of teachers teaching mentally retarded students regarding some variables (Izmir province sample)]. Pamukkale Üniversitesi Ë̆itim Fakültesi Dergisi, 18(18), 1-10.

Guglielmi, R. S., \& Tatrow, K. (1998). Occupational stress, burnout, and health in teachers: A methodological and 
theoretical analysis. Review of educational research, 68(1), 61-99. https://doi.org/10.3102/00346543068001061

Güneş, İ., Bayraktaroğlu, S., \& Özen, K. R. (2009). Çalışanların örgütsel bağl1lık ve tükenmişlik düzeyleri arasındaki ilişki: Bir devlet üniversitesi örneği [A relationship on organizational commitment of employess and burnout level: Sample from a state university]. Süleyman Demirel Üniversitesi İktisadi ve İdari Bilimler Fakültesi Dergisi, 14(3), 481-497.

Güney, S. (2011). Örgütsel davranış [Organizational behaviour]. Ankara: Nobel Yayıncılık.

Haghani, S. R., Hazraty, M., \& Moosivand, M. (2016). The relationship between burnout and organizational commitment with role of moderator of demographic variables (Case study: Social security organization of West department of Mazandaran province). The Turkish Online Journal of Design, Art and Communication, 6, 1834-1840.

Harrison, B. J. (1999). Are you destined to burn out? Fund Raising Management, 30(3), 25-27.

Hock, R. (1988). Professional burnout among public school teachers. Public Personel Management, 17 (2), 123-126. https://doi.org/10.7456/1060AGSE/065

Jacobson, D. A. (2016). Causes and effects of teacher burnout. Doctoral Thesis. Walden University, Minnesota, USA.

Karacan, A. (2012). Özel eğitim kurumlarındaki eğitilebilir ve öğretilebilir bireylerle çalışan öğretmenlerin mesleki tükenmişliklerinin incelenmesi "İstanbul ili Anadolu yakası örneği" [An investigation about the level of burnout of the teachers who work with individuals can be trained and taught at the private educational institues: The case of Anatolian side of Istanbul]. Unpublished Master's thesis. Maltepe Üniversitesi Sosyal Bilimler Enstitüsü, İstanbul.

Kaya, A., Balay, R., \& Tinaz, S. (2014). The Relationship between Managerial Effectiveness and Organizational Commitment Perceptions of Teachers and Principals. Ahi Evran University Journal of Kırşehir Education Faculty (KEFAD), 15(2), 79-97.

Kırılmaz, A. Y., Çelen, Ü., \& Sarp, N. (2003). İlköğretim'de çalışan bir öğretmen grubunda "tükenmişlik durumu" araştırması [A study on burnout with a group of primary school teachers]. Ilköğretim Online, 2(1), 2-9.

Koustelios, A. (2001). Organizational factorsas predictors of teachers' burnout. Psycho Rep, 88(3), 627-634. https://doi.org/10.2466/pr0.2001.88.3.627

Kul, M., \& Güçlü, M. (2010). Okul yöneticilerinin liderlik stilleri ile beden eğitimi öğretmenlerinin örgütsel bağlllıkları arasındaki ilişki [The relationship between school administrators' leadership style and physical education teachers' organizational commitment]. Uluslararası Insan Bilimleri Dergisi, 7(2), 1021-1038.

Kushman, J. W. (1992). The organizational dynamics of teacher workplace commitment: A study of urban elementary and middle schools. Educational administration quarterly, 28(1), 5-42. https://doi.org/10.1177/0013161X92028001002

Li, Y. (2014). Building affective commitment to organization among Chinese university teachers: the roles of organizational justice and job burnout. Educational Assessment, Evaluation and Accountability, 26(2), 135-152. https://doi.org/10.1007/s11092-014-9192-3

Liu, Y., \& Bellibas, M. S. (2018). School factors that are related to school principals' job satisfaction and organizational commitment. International Journal of Educational Research, 90, 1-19. https://doi.org/10.1016/j.ijer.2018.04.002

Luthans, F. (1995). Organizational Behavior, 7th ed., McGraw-Hill, New York, NY.

Martin, C. L., \& Bennett, N. (1996). The role of justice judgments in explaining the relationship between job satisfaction and organizational commitment. Group \& Organizational Management, 21(1), 84-104. https://doi.org/10.1177/1059601196211005

Maslach, C., \& Jackson, S. E. (1981). The measurement of experienced burnout. Journal of Organizational Behavior, 2(2), 99-113. https://doi.org/10.1002/job.4030020205

Maslach, C., Schaufeli, W. B., \& Leiter, M. P. (2001). Job burnout. Annual review of psychology, 52(1), 397-422. https://doi.org/10.1146/annurev.psych.52.1.397

Meydan, C. H., Basım, H. N., \& Çetin, F. (2011). Örgütsel adalet algısı ve bağlılı̆̆ın tükenmişlik üzerine etkisi: Türk kamu sektöründe bir araştırma [The effect of organizational justice perception and organizational commitment on burnout: An investigation on Turkish public sector]. Bilig, 57, 175-200.

Muller, S. M., Gorrow, T. R., \& Fiala, K. A. (2011). Considering Protective Factors as a Tool for Teacher Resiliency. Education, 131(3). 
Nagar, K. (2012). Organizational commitment and job satisfaction among teachers during times of burnout. Vikalpa, $37(2), 43-60$.

Özdemir, B., \& Demir, A. (2017). Romantic relationship satisfaction, age, course load, satisfaction with income and parental status as predictors of instructors' burnout: Evidence from a correlational study. Current Psychology, 1-16. https://doi.org/10.1007/s12144-017-9724-3

Sajid, H. (2014). A comparison of organizational commitment and job burnout among teachers in private and public institution with moderating effect of job satisfaction. IOSR Journal of Business and Management, 16(6), $29-33$. https://doi.org/10.9790/487X-16642933

Sari, R. L., \& Seniati, A. N. L. (2018). The role of professional commitment as a mediator in the relationship between job satisfaction and organizational commitment among lecturers in higher-education institutions. Diversity in Unity: Perspectives from Psychology and Behavioral Sciences.

Sarros, J. C., \& Sarros, A. M. (1987). Predictors of teachers burnout. The Journal of Educational Administration, 14(2), 272-280. https://doi.org/10.1108/eb009933

Sezer, F. (2005). İlköğretim okulu müdürlerinin sergiledikleri liderlik stillerinin öğretmenlerin örgütsel bağlılığına etkisi [Impacts of the leadership styles of the elementry school principles upon the organisational commitment of the teachers]. Unpublished Master's thesis. Gazi Üniversitesi, Sosyal Bilimler Enstitüsü, Ankara.

Shirazi, R. R., Beiki, Y., Zamanian, F., \& Esapour, K. (2011). Study of the relationship between organizational commitment and job burnout among physical education teachers of Golestan Province, Iran. Australian Journal of Basic and Applied Sciences, 5(10), 1379-1384.

Sucuoğlu, B., \& Kuloğlu, N. (1996). Özürlü çocuklarla çalışan öğretmenlerde tükenmişliğin değerlendirilmesi [An evaluation of burnout for teachers teaching disabled children]. Türk Psikoloji Dergisi, 10(36), 44-60.

Şahin, D. (2007). Öğretmenlerin tükenmişlik düzeyinin farklı değişkenler açısından incelenmesi [An investigation of teachers' burnout levels regarding various variables]. Unpublished Master's thesis. Gazi Üniversitesi, Sosyal Bilimler Enstitüsü, Ankara.

Togia, A. (2005). Measurement of burnout and the influence of background characteristics in Greek academic librarians. Library Management, 26(3), 130-138. https://doi.org/10.1108/01435120510580870

Toker, B. (2011). Burnout among university academicians: an empirical study on the universities of Turkey. Doğuş Üniversitesi Dergisi, 12(1), 114-127. https://doi.org/10.31671/dogus.2019.155

Tuğrul, B., \& Çelik, U. P. E. (2002). Normal çocuklarla çalışan anaokulu öğretmenlerinde tükenmişlik [Burnout for kindergarten teachers teaching normal children]. Pamukkale Üniversitesi Eğitim Fakültesi Dergisi, 12(12), 1-11.

Ulutaşdemir, N. (2012). Kilis kent merkezinde görev yapan öğretmenlerin tükenmişlik düzeyleri ve etkileyen faktörlerin incelenmesi [The burnout level of the teachers who work in the centre of kilis and the research of the factors effecting them]. Unpublished PhD dissertation. Fırat Üniversitesi Sağlık Bilimleri Enstitüsü, Elazig.

Vandenberg, R. J., \& Scarpello, V. (1994). A longitudinal assessment of the determinant relationship between employee commitments to the occupation and the organization. Journal of Organizational Behavior, 15(6), 535-547. https://doi.org/10.1002/job.4030150605

Werang, B. R., Asmaningrum, H. P., \& Irianto, O. (2015). Relationship between teachers' job burnout, teachers' organizational commitment and teachers job performance at state elementary schools in Boven Digoel Regency, Papua, Indonesia. International Journal of Science and Research, 4(2), 826-830.

Wiener, Y. (1982). Commitment in organizations: A normative view. Academy of Management Review, 7(3), 418-428. https://doi.org/10.5465/amr.1982.4285349

Yasmin, K., \& Marzuki, N. A. (2015). Organizational commitment and job burnout among psychaitric nurses in Punjab Pakistan. Journal of Sociological Research, 6(2), 138-149. https://doi.org/10.5296/jsr.v6i2.8693

\section{Copyrights}

Copyright for this article is retained by the author(s), with first publication rights granted to the journal.

This is an open-access article distributed under the terms and conditions of the Creative Commons Attribution license which permits unrestricted use, distribution, and reproduction in any medium, provided the original work is properly cited. 